\title{
Online learning: Best practices in practice
}

\author{
Angela van Barneveld \\ Lakehead University \\ avanbar@lakeheadu.ca
}

\begin{abstract}
This paper provides a summary the predominant best practices for asynchronous online teaching and learning, as well as the characteristics of an effective online instructor. The author then shares implementation strategies and experiences of integration of these best practices into her online teaching practice, explaining what is done and how it is done, and how that relates to learner engagement.
\end{abstract}

Keywords: asynchronous, best practices, implementation, online learning, teaching and learning

\section{INTRODUCTION}

Online learning appears to be both established and emerging as a strategic initiative for universities and faculty are being asked to deliver their classes in an online format to support these academic and strategic plans. The research literature presents us with best practices for teaching and learning [5], online learning [3][4], and characteristics of effective online instructors [11]. Instructors/faculty are being encouraged to move to online course delivery [1] with little or no preparation or training, and possibly without the assistance of a Teaching and Learning Center.

\section{LITERATURE REVIEW}

To an extent, best practices in teaching and learning are best practices in teaching and learning. Chickering and Gamson's [5] seminal work on undergraduate teaching highlighted seven principles of good practice. This work was later augmented to include the integration of information and communication technologies to support these principles [4]. Johnson [8] applied the principles successfully to an online health course, and cautioned that "online teaching does not in and of itself equate to quality teaching" (p. 47). This research emphasized the need for expectations to be communicated clearly, and for the need of ongoing faculty development concerning technology and online teaching strategies. Arbaugh [1] applied the principles to an online graduatelevel business course. While the analysis did not find strong support for all the principles, Arbaugh noted that there was significant evidence of positive impact of student collaboration, prompt feedback, time on task, and student-faculty contact on perceived learning.

More recently, best practices with specific reference to online teaching and learning have emerged.

\subsection{Characteristics of good teaching}

Principles of good classroom teaching practice indicate that the instructor would (1) encourage contact between students and faculty, (2) develop reciprocity and cooperation among students, (3) use active learning techniques, (4) give prompt feedback, (5) emphasize time on task, (6) communicate high expectations, and (7) respect diverse talents and ways of learning [4][5].

Learner engagement is as important, if not more so, in an online setting as it is in a traditional classroom [3][11]. Learner engagement is defined as “... to comprise active and collaborative learning, participation in challenging academic activities, formative communication with academic staff, involvement in enriching educational experiences, and feeling legitimated and supported by university learning communities” [6, p. 122]. While typical interactions occur between the learner and the instructor/content/other learners, there is an additional component of engagement with the course site interface. This engagement emphasizes the need for organization, accessibility, and flow to be designed into the course and the structure of the course site in order to facilitate a good learning experience.

\subsection{Characteristics of an excellent online instructor}

The research into excellence in online instruction has produced sets of characteristics that, on the one hand, emphasize that transferability of skills between classroom and online teaching [2] and, on the other, the uniqueness of characteristics to the online environment.

Savery [13] developed the VOCAL acronym and associated strategies to reinforce the need for the online instructor to be visible, organized, compassionate, analytical, and leader-by-example (p. 142). 
Palloff and Pratt [11] listed the characteristics of an excellent online instructor as:

1. highly motivated and is a good motivator for learners

2. promotes interactivity

3. incorporates collaborative work

4. respects learners as partners in the learning process

5. is active and engaged, providing timely and constructive feedback

6. open, flexible, responsive, leads by example

7. able to establish presence early in the course

8. understands importance of community building

9. understands the difference between face-to-face and online

10. committed to this form of teaching.

While all these characteristics are relevant to online instructors, it is evident that \#1-6 are also applicable to any instructor with a learner-centered approach, whether online or traditional classroom. This reinforces the transferability of some characteristics and skills from a classroom to an online environment [2]. While moving to an online environment does require different design and engagement considerations, instructors who are new to online learning are not entering the arena as a blank slate. This awareness may lessen the anxiety of engaging in online teaching.

\subsection{Best practices for online learning}

Farmer and Ramsdale [7] proposed a set of online teaching competencies. These include being able to support the learners with the use of course-specific tools and technology; to establish community and foster proper netiquette; to design learning activities that are engaging, participatory, and promote learner interaction; to support alignment of learning objectives, learning activities, and assessment strategies through good instructional design; and to serve as a model to guide and support learners.

The work of Boettcher and Conrad [3] and Palloff and Pratt [11] are oft cited in literature and on university teaching and learning sites. See Table 1 for their components of best practices for online learning.

Table 1: Best practices for online learning.

\begin{tabular}{|l|l|}
\hline \multicolumn{1}{|c|}{ Boettcher \& Conrad } & \multicolumn{1}{|c|}{ Palloff \& Pratt } \\
\hline $\begin{array}{l}\text { Be present at the course } \\
\text { site }\end{array}$ & $\begin{array}{l}\text { Establish presence early } \\
\text { in the course - have } \\
\text { learners do the same }\end{array}$ \\
\hline $\begin{array}{l}\text { Use a variety of large } \\
\text { group, small group, and } \\
\text { individual work }\end{array}$ & $\begin{array}{l}\text { Promote interactivity } \\
\text { between students }\end{array}$ \\
\hline $\begin{array}{l}\text { Create a supportive online } \\
\text { course community }\end{array}$ & $\begin{array}{l}\text { Devote time at the start } \\
\text { of class to community } \\
\text { building }\end{array}$ \\
\hline
\end{tabular}

\begin{tabular}{|l|l|}
\hline $\begin{array}{l}\text { Prepare discussion posts } \\
\text { that engage learners with } \\
\text { content }\end{array}$ & $\begin{array}{l}\text { Incorporate collaborative } \\
\text { work }\end{array}$ \\
\hline $\begin{array}{l}\text { Share a set of very clear } \\
\text { expectations for your } \\
\text { students/self }\end{array}$ & $\begin{array}{l}\text { Provide timely and } \\
\text { constructive feedback } \\
\text { throughout }\end{array}$ \\
\hline $\begin{array}{l}\text { Combine core and } \\
\text { personalized content }\end{array}$ & \\
\hline
\end{tabular}

While some of these best practices seem to be applicable to both classroom and online learning, there are also elements that are unique to the online class [12]. The online instructor's role, in additional to the traditional pedagogical and social components now takes on managerial and technical components in an online setting. Further, the environment provides an anytime-any place flexibility and allows time for reflection prior to engagement [10].

In a summarization of the best practices for online teaching and learning, the predominant practices seem to be:

- be present

- $\quad$ set expectations and communicate clearly

- create a supportive online course community

- $\quad$ provide timely and effective feedback

- $\quad$ combine core concept with personalized learning

The combination of excellent instructor characteristics and best practices for online teaching and learning are important components for an effective learning online learning experience. How these best practices are implemented in actual practice may vary. The next section offers examples of how this researcher/instructor integrates best practices into her online classes.

\section{BEST PRACTICES IN PRACTICE}

Given the separation in time and space, interaction and the development of community takes on greater importance in an asynchronous online environment, where instructors and learners can neither see nor, usually, hear each other. Therefore, the establishment of presence, the engagement of learners, and the building of community early in the course are imperative.

\subsection{Early engagement of learners}

3.1.1. Pre-class survey. About $3-4$ weeks prior to the start of the course, I send my learners a welcome email and a link to an online pre-class survey. The purpose of the survey to get to know my learners, establish my learners, to establish my presence, to inform course design, to encourage their contribution, to establish their accountability, and to start to build community. Two 
reminder emails are sent out up to one week prior to course start. After compiling the survey data, the results and their impact on the course design are shared back with the learners in a Course Orientation video that is posted in the course site and available in the week prior to the start of the course.

3.2.1. Course orientation video. Within one week of the start date, the course site made active and this video is available to the learners. The purpose of this video is to introduce and explain the structure and flow of the course. It includes information on the rhythm of the course, giving and getting feedback, how we will address questions and any bumps or technical glitches during the course, and a description of roles and responsibilities as the learner and as the instructor.

3.1.3. Introduce yourself. In the first week of the course, learners are directed to a discussion forum to post their introductions. My instructor introduction is pinned to the top of the discussion forum so that it is the first one that learners see when they enter the space. Learners are asked to reply to what might be considered standard questions such as a short bio, a fun fact, and why they chose this program. The intent here is to maintain instructor presence and to start to build a class community. Perhaps less typical are the additional questions that learners are asked to address related to their goals and expectations.

They say that you never get a second chance to make a first impression, and the launch of an asynchronous online course is no exception. Learner engagement is a pillar of any successful online course. Critical best practices to foster and support that engagement early in the course include (1) the establishment of instructor presence, (2) set clear expectations, and (3) start to build community.

\subsection{Ongoing engagement of learners}

3.2.1. Spaces for interactivity - discussions. One of the primary spaces for learning in an online course is the discussion forum. Therefore, in the formal weekly discussion forums, the design of the learning experience must consider the level cognitive, social, and teaching presence to engage the learners in meaningful and deep learning [8]. The formal discussion forums focus on practicing higher order thinking skills, individual and group activities and, whenever possible, learner choice. Discussion forums can also support informal learner engagement. In a general discussion area, I create three discussion forums. The Water Cooler is a space for learners to talk amongst themselves. There are no instructors in the discussion, but learners are advised that I can see the content of the forum. The second informal space is Shared Resources, where learners can post links, articles, pictures, or any resource they think would be of benefit or interest to the class. And the final informal space is the Ask a Peer/Ask the Instructor forum, where learners can pose questions about the course or content and response are provided by their peers or by me, the instructor. These informal online spaces foster community through peer-peer and peer-instructor interaction. They also reinforce the importance of presence and accountability of learners to the whole group.

3.2.2. Midterm survey. I send learners this online survey just after the midpoint of the course. It contains four questions. Thus survey serve as a temperature checkpoint to see how things are going and, given the learner feedback, informs me of any quick (and feasible) adjustments I can make to the course to enhance the learning experience. As with the pre-class survey, I compile the data and share the aggregated results and outcomes back to the learners.

3.2.3. Feedback. Learners are advised in the Course orientation video that feedback will be a process of giving and getting, from peers and from me, and that they should consider everything that they do (and/or don't do) as a form of feedback. I coach and model how to give actionable and constructive. Formative feedback is provided during discussion forums and in the weekly wrap up videos that summarize the intention, key points, and take-aways from the weeks' learning activities. Summative feedback is provided with all grading elements (discussions, assignments). Finally, feedback to learners is provided after each survey - pre-class, midterm, and course evaluations. Their aggregated ideas are acknowledged and my explanations as to what I can change and what I cannot (and why) are shared.

Critical best practices to foster and support that ongoing learner engagement in the course include (1) maintaining the presence of the instructor, (2) giving actionable feedback early and often, and (3) intentionally creating spaces for formal and informal interaction.

\section{FINAL THOUGHTS}

The focus on learner engagement in an asynchronous online learning course is imperative. These interactions must be intentionally designed into the learning experience and would ideally engage the learners before the course even starts. Knowing who your learners are before they come to your online class allows you to not only consider options to customize the course, but also allows you to prepare any additional resources to support learners who may be new the online learning environment. The instructor's presence throughout the course is important, and serves as a model for feedback, appropriate behavior, and engagement. 


\section{References}

[1] Allen, I. E.. \& Seaman, J. (2012). Conflicted: Faculty and online education, 2012. Retrieved from https://www.insidehighered.com/sites/default/server files/fil es/IHE-BSRG-Conflict.pdf

[2] Arbaugh, J. B., \& Hornick, S. (2006). Do Chickering and Gamson's seven principles also apply to online MBAs? The Journal of Educators Online, 3(2), 1-18.

[3] Boettcher, J., V., \& Conrad, R.-M. (2010). The online teaching survival guide: Simple and practical pedagogical tips. San Francisco, CA: Jossey-Bass.

[4] Chickering, A. W., \& Ehrmann, S. C. (1996). Implementing the seven principles: Technology as lever. AAHE Bulletin, 49(2), 3-6.

[5] Chickering, A. W., \& Gamson, Z. F. (1987). Seven principles for good practice in undergraduate education. AAHE Bulletin, 39(March), 3-7.

[6] Coates, H. (2007). A model of online and general campusbased student engagement. Assessment \& Evaluation in Higher Education, 32(2), 121-141.

[7] Farmer, H. M., \& Ramsdale, J. (2016). Teaching competencies for the online environment. Canadian Journal of Learning and Technology, 42(3), 1-17. Available at http://www.cjlt.ca/index.php/cjlt/article/view/27471

[8] Garrison, D. R., Anderson, T., \& Archer, W. (2000). Critical inquiry in a text-based environment: Computer conferencing in higher education. The Internet and Higher Education, 2(2-3), 87-105. doi:http://dx.doi.org/10.1016/S1096-7516(00)00016-6

[9] Johnson, S. (2014). Applying the seven principles of good practice: Technology as a lever - in an online research course. Journal of Interactive Online Learning, 13(2), 4150 .

[10] Keengwe, J., \& Kidd,T.T. (2010). Towards best practices in online learning and teaching in higher education. MERLOT Journal of Online Teaching and Learning, 6(2), 533-541.

[11] Palloff, R. M., \& Pratt, K. (2011). The excellent online instructor: Strategies for professional development. San Francisco, CA: Jossey-Bass.

[12] Ragan, L. C. (2015). 10 Principles of effective online teaching: Best practices in distance education. Retrieved from http://cdn.facultyfocus.com/wpcontent/uploads/2015/02/10-Principles-of-Effective-OnlineTeaching.pdf

[13] Savery, J. (2005). BE VOCAL: Characteristics of successful online instructors. Journal of Interactive Online Learning, 4(2), 141-152. Available at http://www.ncolr.org/jiol/issues/pdf/4.2.6.pdf 